Journal of Southeast Asian

\title{
A Historical Analysis of Southeast Asian Refugee Communities: Post-war Acculturation and Education in the U.S.
}

\author{
Stacy M. Kula \\ Claremont Graduate University, stacy.m.kula@gmail.com \\ Susan J. Paik \\ susan.paik@cgu.edu
}

Follow this and additional works at: https://docs.lib.purdue.edu/jsaaea

Part of the Educational Sociology Commons, Other Education Commons, and the Quantitative, Qualitative, Comparative, and Historical Methodologies Commons

\section{Recommended Citation}

Kula, Stacy M. and Paik, Susan J. (2016) "A Historical Analysis of Southeast Asian Refugee Communities: Post-war Acculturation and Education in the U.S.," Journal of Southeast Asian American Education and Advancement: Vol. 11 : Iss. 1, Article 1.

DOI: $10.7771 / 2153-8999.1127$

Available at: https://docs.lib.purdue.edu/jsaaea/vol11/iss1/1

This document has been made available through Purdue e-Pubs, a service of the Purdue University Libraries. Please contact epubs@purdue.edu for additional information.

This is an Open Access journal. This means that it uses a funding model that does not charge readers or their institutions for access. Readers may freely read, download, copy, distribute, print, search, or link to the full texts of articles. This journal is covered under the CC BY-NC-ND license. 


\title{
USAAEA Journal of Southeast Asian American
Education and Advancement
}

Volume 11 (2016) $\quad$ www.JSAAEA.org

\section{A Historical Analysis of Southeast Asian Refugee Communities: Post-war Acculturation and Education in the United States}

\author{
Stacy M. Kula \& Susan J. Paik \\ Claremont Graduate University
}

\begin{abstract}
This analysis considers the circumstances of Southeast Asian refugee immigration following the Vietnam War as well as the political and social environment in the U.S. upon their arrival, in order to examine the historical factors that link to their subsequent educational trends. Receptive government policies enabled these communities to survive; however, with the exception of first-wave Vietnamese refugees, their limited job skills, English language knowledge, and education upon arrival were exacerbated by overall prejudiced societal reception and the lack of an existing co-ethnic community to buffer their entry into U.S. society. All groups have generally experienced low academic achievement except in the case of Vietnamese Americans, for whom a notable contingent demonstrates higher attainment. Implications for subsequent generations, and for research and practice, are discussed.
\end{abstract}

Keywords: Southeast Asian, refugee, historical analysis, educational trends, modes of incorporation

\section{Introduction and Significance of the Topic}

Southeast Asians comprise a unique subset of the Asian American population in the United States for many reasons. One is their relatively recent arrival after the Vietnam War, unlike other Asian American immigration waves (e.g., East, South Asian, Filipinos) that can be traced as far back to the late 1800s (Rumbaut, 2000). Their post-war arrival as refugees also made their experiences unique compared to traditional immigrants. Though other Southeast Asian groups

\footnotetext{
(c)

SDRERIIGHISRESERNEDR Readers are free to copy, display, and distribute this article, as long as the work is attributed to the author(s) and the Journal of Southeast Asian American Education \& Advancement, it is distributed for non-commercial purposes only, and no alteration or transformation is made in the work. More details of this Creative Commons license are available at http://creativecommons.org/licenses/by-nc-nd/3.0/. All other uses must be approved by the author(s) or JSAAEA.

Journal of Southeast Asian American Education \& Advancement, Vol. 11 (2016) ISSN: 2153-8999
} 
(e.g., Indonesians, Thai) would immigrate in notable numbers in the early 1980s, Vietnamese, Laotian, and Cambodian refugees were the first to arrive in the U.S. (Takaki, 1998). Fraught with barriers before and after their arrival, their integration and acculturation into the U.S. has been less than favorable in terms of their overall educational and economic outcomes (Rumbaut, 2000). Despite these unique experiences, Southeast Asian Americans are often lumped together with other Asian groups. They experience similar racial stereotypes as the "model minority" or other shared racialized perceptions, but they have very unique experiences, outcomes, and needs than other Asian groups. Thus, they remain misunderstood and poorly served by the educational system (Blair \& Qian, 1998). It is vital that scholars and practitioners alike understand the background and historical experiences of Southeast Asian American communities, in order to better support and address current educational issues for students and their families.

The purpose of this article is to provide a historical analysis of Southeast Asian immigrant experiences and the linkage to their educational trajectory. Based on the Asian American modes of incorporation framework (Paik, Kula, Saito, Rahman \& Witenstein, 2014), this article will include the following: (a) current demographic data including population and educational attainment of Southeast Asian American groups; (b) historical data detailing the events surrounding Southeast Asian refugee immigration to the U.S.; and (c) the infrastructure and resources available to these groups in the U.S. Historical perspectives shed light on how past experiences inform the present; these linkages of immigration context and subsequent educational trends can help inform practice and policy recommendations for Southeast Asian American communities. Because of the need to better understand the unique experiences of Southeast Asian groups, the historical analysis and discussion will include the similarities and differences in their immigration, acculturation, and educational experiences and other outcomes.

While there is great diversity in Southeast Asian American populations, this article will include only those groups admitted under the Indochinese Refugee Act of 1975: Vietnamese, Laotian (or Lowland Lao), Hmong (or Highland Lao), and Cambodians. These groups constitute not only the largest Southeast Asian populations ${ }^{1}$ (Hoeffel, Rastogi, Kim, \& Shahid, 2012), but also the only Southeast Asian American groups to have come in initial large waves to the U.S. as refugees.

\section{Theoretical Framework}

The theoretical framework is based on the "Asian American modes of incorporation" by Paik et al. (2014), an adapted version of Portes and Rumbaut's (1990, 2001) "modes of incorporation." Paik et al. (2014) used their adapted model to understand the historical analysis of immigration and education trends of diverse Asian American groups. The framework consists of four key factors: (a) Government Policy, (b) Societal Reception, (c) Co-ethnic Communities, and (d) Barriers \& Opportunities. The first three factors use Portes and Rumbaut's original conceptions of how type of acculturation and adaptation affect immigrant experiences. The fourth factor, 
Barriers and Opportunities (described below), was modified for Asian American immigrant experiences (Paik et al., 2014).

Each of the four factors is categorized as positive, negative, or neutral experiences. For example, government policy is characterized as "hostile" if immigration is illegal, "indifferent" if it is legalized, and "receptive" if it is encouraged. Societal reception by immigrants is "prejudiced," "neutral" or "unprejudiced." The nature of co-ethnic communities are conceived not as social networks, but as resource networks (e.g., educational or occupational opportunities, information, etc.) within each ethnic group, particularly to newcomers who would not otherwise have access to such resources themselves.

Co-ethnic communities are characterized as "strong" if the group consists of a high percentage of professionals, highly educated individuals who live in areas of high ethnic concentration. They are characterized as "neutral" in cases where the group may be comprised of professionals and have a high level of average education, but remains dispersed into more diverse communities rather than concentrated into specific geographic areas. In cases where the ethnic groups do not have a high percentage of professionals or a high level of education on average, the co-ethnic community is considered to be "weak" regardless of the level of concentration of the population.

Portes and Rumbaut's theory also indicates that "individual features" (e.g., English knowledge, prior education, job skills, and wealth) and "family features" (e.g., intact family unit headed by two parents) are also predictive of acculturation and adaptation patterns; this area was adapted by Paik et al. (2014) to include factors more specifically linked to outcomes for Asian American groups. Specifically, instead of individual and family features, the adapted version includes one area called Other Barriers and Opportunities, which includes the following: (a) the time of arrival (pre-or post-1965, when the Immigration Act legalized immigration from Asia, enabling a more favorable environment for immigrant groups); (b) settlement places (coastal or inland, with coastal settlement granting more opportunity for the formation of and access to strong co-ethnic communities); (c) class status/SES (with higher status granting more opportunity); (d) occupation (professional or working class, with professional and entrepreneurial fields yielding benefits); (e) education level (with higher average educational attainment linked to greater opportunity); and (f) English language ability (with facility in English upon arrival supporting positive group outcomes). These factors tended to play a role in the types of opportunities granted to or barriers faced by Asian American groups (Paik et al., 2014).

In general, the theory predicts that for any immigrant group, the greater the number of positive factors present in the historical context of their arrival, the greater their chances for positive acculturation and adaptation experiences and eventual success in terms of educational outcomes; on the other hand, those groups that experience more negative factors will face multiple barriers to acculturation and adaptation and will experience lower educational outcomes. While the theory does not posit a direct link between the number of positive or negative factors and the upward or downward mobility of a group, it does provide a lens through 
which to understand some of the trends that can be seen for different Asian immigrant groups, including Southeast Asian Americans, and can inform those who work with these groups in educational settings to understand some of the issues that have arisen through their history and their context of immigration, which have ramifications in their experience today.

\section{Southeast Asian Communities in the U.S.: Current Demographic, Educational, and Occupational Data}

Southeast Asia is a large and diverse region consisting of the countries of Brunei, Cambodia, East Timor, Indonesia, Laos, Malaysia, Philippines, Singapore, Thailand, and Vietnam (Joseph \& Matthews, 2014). This study will exclude the island and peninsular countries that are part of "Insular" or "Maritime Southeast Asia"-Brunei, Indonesia, Malaysia, Philippines, Singapore, East Timor - and concentrate on the Indochinese or mainland Southeast Asian countries of Cambodia, Laos, and Vietnam. Thailand will not be considered because of its distinct immigration history compared to the other three nations whose immigration occurred largely under refugee status.

When considering the three Indochinese countries of Cambodia, Laos, and Vietnam, four ethnic groups are formally recognized by the U.S. Census: Vietnamese, Cambodian (Khmer), Laotian, and Hmong (Hoeffel et al., 2012). In reality, many other distinct ethnic groups arrived from these countries, including ethnic Lao, Mien, Khmer Loeu, Montagnards, and Chinese ethnics (Hmong Studies Internet Resource Center [HSIRC], 2011). However, upon arrival in the U.S., the more specific ethnic status of these groups was not tracked, and therefore the data aggregates refugees into the four aforementioned groups only. Therefore, this paper will use the same four monikers to describe the immigrant groups under study.

Southeast Asian American groups have grown consistently in numbers since their arrival as refugees starting in the mid-1970s; together, according to the 2010 U.S. Census as reported by Hoeffel et al. (2012), they number approximately 2.5 million individuals. However, by far the largest of these groups is the Vietnamese American community, at 1.7 million people, representing almost two-thirds of the total Southeast Asian population. Cambodian Americans, at 276,000, Hmong Americans, at 260,000, and Laotian Americans, at 232,000, have a combined total that is less than half the size of the Vietnamese Americans (United States Census Bureau [USCB], 2010). Growth in the population of Vietnamese Americans has come both through the birth and growth of new American-born generations as well as through continued immigration from Vietnam. Growth from Cambodian, Hmong, and Laotian groups is now almost exclusively due to birth rates within the U.S., as immigration has slowed to almost zero since the closure of the last refugee camps in Thailand (Department of Homeland Security [DHS], 2010; Niedzwiecki \& Duong, 2011). 
Kula \& Paik - A Historical Analysis of Southeast Asian Refugee Communities

\section{Table 1}

Current population of Southeast Asian groups according to 2010 U.S. Census.

\begin{tabular}{lrrr}
\hline Ethnic Group & \multicolumn{1}{c}{$\begin{array}{c}\text { Population } \\
\text { (alone) }\end{array}$} & $\begin{array}{c}\text { Population } \\
\text { (alone or in any } \\
\text { combination) }\end{array}$ & $\begin{array}{c}\text { \% of Asian } \\
\text { American pop'n } \\
(17,320,856)\end{array}$ \\
\hline Vietnamese & $1,632,717$ & $1,737,433$ & 10.0 \\
Cambodian & 255,497 & 276,667 & 1.6 \\
Hmong & 252,323 & 260,073 & 1.5 \\
Laotian & 209,646 & 232,130 & 1.3 \\
\hline
\end{tabular}

Source: (Hoeffel et al., 2012)

Though Southeast Asian groups are relatively more dispersed across the nation than many other Asian groups, such as East Asians or South Asians (Paik et al., 2014), almost onethird of each group's population lives in California alone (HSIRC, 2011). Vietnamese American communities have tended to reside in coastal states, particularly in the western and southern U.S. regions, including Texas, Washington, Florida, and Virginia. Cambodian American groups have settled in coastal states as well, particularly in western and eastern U.S. states, with Massachusetts, Washington, Texas, and Pennsylvania each housing at least $10 \%$ of their population. Hmong have settled uniquely in Midwestern states, with Minnesota and Wisconsin nearly accommodating as much of their population as California. Laotians are by far the most dispersed group, such that no states house a large percentage of their population after California. However, notable Laotian communities do exist, particularly in the states of Texas, Minnesota, and Washington (Bankston, 2000).

In terms of educational and occupational trends, Southeast Asian American groups overall experience lower attainment than the overall Asian American population as well as the U.S. average rates (Niedzwiecki \& Duong, 2011). This means that more individuals from this group do not hold a high school diploma, and fewer have bachelors and graduate degrees, compared with other groups. The statistics are somewhat mitigated by the fact that the Vietnamese American group experiences relatively higher attainment than other Southeast Asian groups, with a substantial percentage attaining bachelor's and graduate degrees; however, the overall attainment of the Vietnamese American population still falls below that of the total Asian American population (Niedzwiecki \& Duong, 2011). 
Journal of Southeast Asian American Education and Advancement, Vol. 11 [2016], Iss. 1, Art. 1

Kula \& Paik - A Historical Analysis of Southeast Asian Refugee Communities

Table 2

Number of refugees admitted from Cambodia, Laos, and Vietnam, 1975-2010

\begin{tabular}{|c|c|c|c|c|}
\hline \multirow{2}{*}{ Fiscal Year } & \multicolumn{3}{|c|}{ Number of Refugees from } & \multirow{2}{*}{$\begin{array}{c}\text { S.E. Asian } \\
\text { Refugee Total }\end{array}$} \\
\hline & Cambodia & Laos* & Vietnam & \\
\hline 1975 & 4,600 & 800 & 125,000 & 130,400 \\
\hline 1976 & 1,100 & 10,200 & 3,200 & 14,500 \\
\hline 1977 & 300 & 400 & 1,900 & 2,600 \\
\hline 1978 & 1,300 & 8,000 & 11,100 & 20,400 \\
\hline 1979 & 6,000 & 30,200 & 44,500 & 80,700 \\
\hline 1980 & 16,000 & 55,500 & 95,200 & 166,700 \\
\hline 1981 & 38,194 & 19,777 & 65,279 & 123,250 \\
\hline 1982 & 6,246 & 3,616 & 27,396 & 37,258 \\
\hline 1983 & 13,041 & 2,907 & 22,819 & 38,767 \\
\hline 1984 & 19,727 & 7,218 & 24,856 & 51,801 \\
\hline 1985 & 19,175 & 5,195 & 25,222 & 49,592 \\
\hline 1986 & 9,845 & 12,313 & 21,700 & 43,858 \\
\hline 1987 & 1,786 & 13,394 & 19,656 & 34,836 \\
\hline 1988 & 2,897 & 14,597 & 17,571 & 35,065 \\
\hline 1989 & 2,162 & 12,560 & 21,924 & 36,646 \\
\hline 1990 & 2,329 & 8,715 & 27,797 & 38,841 \\
\hline 1991 & 179 & 9,232 & 28,396 & 37,807 \\
\hline 1992 & 163 & 7,285 & 26,795 & 34,243 \\
\hline 1993 & 63 & 6,944 & 31,401 & 38,408 \\
\hline 1994 & 15 & 6,211 & 34,110 & 40,336 \\
\hline 1995 & 6 & 3,682 & 32,250 & 35,938 \\
\hline 1996 & 5 & 2,203 & 16,107 & 18,315 \\
\hline 1997 & 9 & 915 & 6,612 & 7,536 \\
\hline 1998 & 7 & 9 & 10,266 & 10,282 \\
\hline 1999 & 0 & 19 & 9,622 & 9,641 \\
\hline 2000 & 0 & 64 & 2,839 & 2,903 \\
\hline 2001 & 23 & 22 & 3,109 & 3,154 \\
\hline 2002 & 0 & 18 & 2,855 & 2,873 \\
\hline 2003 & 4 & 13 & 1,354 & 1,371 \\
\hline $2004 * *$ & 7 & 6,005 & 979 & 6,991 \\
\hline $2005 * *$ & 3 & 8,517 & 2,009 & 10,529 \\
\hline 2006 & 3 & 830 & 3,039 & 3,872 \\
\hline 2007 & 9 & 117 & 1,500 & 1,626 \\
\hline 2008 & 15 & 59 & 1,112 & 1,186 \\
\hline 2009 & 8 & 14 & 1,486 & 1,508 \\
\hline 2010 & 9 & 36 & 873 & 918 \\
\hline Totals & 145,230 & 257,587 & 771,834 & $1,174,651$ \\
\hline
\end{tabular}

Note: Niedzwiecki \& Duong, 2011

*Refugees from Laos include both Laotian and Hmong groups. Disaggregated data is not available.

**The increase of refugees from Laos during the years 2004-2005 represents primarily Hmong who arrived due to the 2003 closure of the Wat Tham Krabok monastery which served as an unofficial refugee camp after all camps were officially closed in the mid-1990s (Migration Policy Institute, 2005).

Journal of Southeast Asian American Education \& Advancement, Vol. 11 (2016) 
Kula \& Paik - A Historical Analysis of Southeast Asian Refugee Communities

Table 3

Six most populous states for each Southeast Asian ethnic group according to 2010 U.S. Census

\begin{tabular}{ccrr}
\hline & $\begin{array}{c}\text { Six Most Populous } \\
\text { States for each S.E. } \\
\text { Asian Group }\end{array}$ & $\begin{array}{c}\text { Number of } \\
\text { residents }\end{array}$ & $\begin{array}{c}\text { Percent of } \\
\text { pop'n living in } \\
\text { state }\end{array}$ \\
\hline \multirow{4}{*}{ Cambodian } & California & 102,317 & $38.23 \%$ \\
& Massachusetts & 28,424 & $10.62 \%$ \\
& Washington & 22,934 & $8.57 \%$ \\
& Texas & 14,347 & $5.36 \%$ \\
& Pennsylvania & 14,118 & $5.27 \%$ \\
Minnesota & 9,543 & $3.57 \%$ \\
\hline & California & 91,224 & $35.08 \%$ \\
& Minnesota & 66,181 & $25.45 \%$ \\
& Wisconsin & 49,240 & $18.93 \%$ \\
& North Carolina & 10,864 & $4.18 \%$ \\
& Michigan & 5,924 & $2.28 \%$ \\
Colorado & 3,859 & $1.48 \%$ \\
\hline \multirow{4}{*}{ Laotian } & California & 69,303 & $29.86 \%$ \\
& Texas & 15,784 & $6.8 \%$ \\
& Minnesota & 12,009 & $5.17 \%$ \\
& Washington & 11,568 & $4.98 \%$ \\
& Tennessee & 7,276 & $3.13 \%$ \\
& Illinois & 7,102 & $3.06 \%$ \\
\hline & California & 647,589 & $25.84 \%$ \\
& Texas & 227,968 & $9.1 \%$ \\
& Washington & 75,843 & $3.03 \%$ \\
& Florida & 65,772 & $2.62 \%$ \\
& Virginia & 59,984 & $2.39 \%$ \\
& Georgia & 49,264 & $1.97 \%$ \\
\hline
\end{tabular}

Source: Niedzwiecki \& Duong, 2011

Occupational trends also reflect a lower educational attainment, as Southeast Asian groups are more likely to have working-class jobs in professions such as production/transportation/ material moving occupations, and less likely to hold jobs in management/business/science/arts, compared with the overall Asian and U.S. populations (Niedzwiecki \& Duong, 2011). As with educational attainment, the Vietnamese American population follows the overall trend, with a larger percentage of its population in working-class industries than the U.S. or Asian American averages, yet a notably larger percentage of its population also holds professional jobs compared with other Southeast Asian groups (Niedzwiecki \& Duong, 2011). 
Kula \& Paik - A Historical Analysis of Southeast Asian Refugee Communities

Table 4

Educational attainment (adults aged 25 and over, ethnic groups reporting alone or in combination) according to 2010 ACS 5-year estimates

\begin{tabular}{crrrrrr}
\hline $\begin{array}{c}\text { Highest degree earned } \\
(25+\text { yrs })\end{array}$ & $\begin{array}{c}\text { U.S. } \\
\text { Overall }\end{array}$ & $\begin{array}{c}\text { Asian } \\
\text { Overall }\end{array}$ & Cambodian & Hmong & Laotian & Vietnamese \\
\hline $\begin{array}{c}\text { Less than high school } \\
\text { diploma }\end{array}$ & 14.9 & 13.9 & 37.2 & 37.8 & 33.8 & 28.4 \\
$\begin{array}{c}\text { High school graduate or } \\
\text { equivalent }\end{array}$ & 29 & 16.5 & 25.2 & 22.9 & 29.2 & 22.0 \\
$\begin{array}{c}\text { Some college or A.A. } \\
\text { degree }\end{array}$ & 28.1 & 20.3 & 22.8 & 24.9 & 24.5 & 23.0 \\
$\begin{array}{c}\text { B.A. degree } \\
\begin{array}{c}\text { Graduate or } \\
\text { professional degree }\end{array}\end{array}$ & 17.6 & 29.6 & 11.6 & 11.7 & 10.0 & 19.2 \\
\hline Source Data retrin & 10.3 & 19.8 & 3.2 & 2.7 & 2.5 & 7.4 \\
\hline
\end{tabular}

Source: Data retrieve via American Factfinder (http://factfinder.census.gov/)

A historical analysis of Southeast Asian American experiences and their modes of incorporation is key to understanding the trends of the overall lower educational attainment for Laotian, Cambodian, and Hmong students, and the higher average attainment (both educational and occupational) for Vietnamese American students. Government and societal reception, the presence and type of co-ethnic communities, and other barriers and opportunities they encountered broadly influence their ability to achieve upward social mobility. In the sections that follow, a history of Southeast Asian refugee experiences surrounding their immigration to the U.S. will be given, followed by an analysis of how these experiences may have influenced their subsequent educational and occupational outcomes. The analysis will conclude with implications for research and practice.

\section{The Southeast Asian Immigration Context: Their Unique History}

For many Asian American groups, their immigration histories are sharply divided into two eras separated by the year 1965, when the Hart-Cellar Immigration Act reversed previous laws prohibiting Asian immigration and created a new, open policy allowing immigration from the continent (Paik et al., 2014). However, the story of Southeast Asian immigration to the U.S. almost entirely begins well into the post-1965 era, with the fall of Saigon to the Viet Cong- the Communist Vietnamese forces - on April 30, 1975. Before this time, immigration to the U.S. from Indochinese nations was almost nonexistent (Rumbaut, 1994, 2000), but the pullout of American and allied forces from the region after this date precipitated one of the largest systematic efforts ever undertaken to find placement for refugees (Desbarats, 1985; Montero \& Dieppa, 1982; Portes \& Rumbaut, 1990).

The massive enterprise of assisting the refugees in their resettlement had to be organized very quickly, as thousands of people packed airports, boats, vehicles, or even fled on foot to leave the region in the days before and the weeks following the fall of Saigon (Montero \& 
Dieppa, 1982). These refugees were routed to makeshift camps in Thailand, the Philippines, and other Asian Pacific islands, then moved to receiving countries. The U.S. and France served as primary destinations in this stage (Montero \& Dieppa, 1982).

In that first year, 1975, the initial wave of refugees who came to the U.S. were routed to one of four camps: Camp Pendleton in California, the first to open on April 28; Fort Chaffee in Arkansas which started receiving refugees on May 2; Eglin Air Force Base in Florida which opened two days later; and Fort Indiantown Gap in Pennsylvania which began its operations on May $28^{2}$ (Montero \& Dieppa, 1982). At these camps, refugees were housed and fed while they were processed for resettlement, and some initial training and education in American life, English language, and/or job skills was offered. Processing involved an interview, physical examination, and registration with voluntary agencies (Volags) that were helping with the resettlement process. Once registered, the Volags searched for sponsors to assist individuals or families with job placement, housing, accessing medical care, and general adjustment to American life (Montero \& Dieppa, 1982). Because of the expense of this assistance, very little of which was covered by the government's meager $\$ 500$-per-refugee stipend given to the agencies, sponsors tended to consist of groups such as religious or other nonprofit organizations rather than individuals. Fully 130,000 individuals were resettled in 1975 alone (Desbarats, 1985; Rumbaut, 1989), a number much higher than had been anticipated by officials (Silverman, 1980). The resettlement camps were closed at the end of 1975, as the refugee crisis was considered to be largely over (Zhou \& Bankston, 2000).

The first wave of refugees is considered to include all who entered the country between 1975 and 1978, the large majority arriving in the first year with much lower numbers afterward-1977, for example, only saw 2,500 refugees admitted to the U.S. (Desbarats, 1985; Rumbaut, 1989). These arrivals were almost entirely Vietnamese, though some Hmong soldiers who had worked with CIA operatives in the Laotian highlands against Viet Cong forces were airlifted along with their families in this first wave, and a very small number of Cambodians also were among the refugee admissions (Desbarats, 1985; Rumbaut, 2000; Trueba, Jacobs, \& Kirton, 1990). First-wave refugees tended to be from the educated, professional, and affluent classes of Vietnam. In the 1975 cohort, for example, around 25\% of the refugees had bachelor's degrees or higher, while nearly $40 \%$ more had graduated from high school; by contrast, just $16 \%$ of the overall Vietnamese population held a high school diploma and a mere 1\% had graduated from college (Desbarats, 1985; Kelly, 1986). These had been city-dwellers, and many had professional, business, and/or managerial experience, as well as some limited knowledge of English (Desbarats, 1985). However, these factors did not ensure their easy adjustment to American life. The trauma of their flight from their home country, of having left family and friends behind, the uncertainty of their current situation, language barriers, downward mobility, and major cultural divides between Vietnamese and American ways of life, were just some of the psychosocial difficulties this group faced (Bach \& Carroll-Seguin, 1986; Montero \& Dieppa, 1982; Silverman, 1980). Additionally, they had little say in their placement and were dispersed 
across all states of the U.S., regardless of where other kin and friends they had made in the camps were placed, or where their own preferences lay (Montero \& Dieppa, 1982).

In general, both the camps and the sponsors were ill-equipped and unprepared to meet the needs of the refugees, particularly in English language translation services, help finding jobs, and caring for their psychological as well as physical well-being (Montero \& Dieppa, 1982; Trueba et al., 1990). Their placement in sponsorships throughout the U.S., in areas where they often were isolated from their kin and from the social networks they had developed in the camps, complicated their adaptation as well (Kelly, 1986). That decision to settle refugees across the U.S. was based on beliefs that dispersion into the general population would assist rapid assimilation as well as reduce burdens on states and communities that would otherwise house a disproportionate number of the refugees. However, in practice, it denied refugees the types of opportunities and supports that would exist in ethnic enclaves to support their adaptation and improve later outcomes (Kelly, 1986; Montero \& Dieppa, 1982; Silverman, 1980).

The actual dispersion of refugees was not perfect, and some states - especially California, where Camp Pendleton, the first and one of the largest camps was operated - ended up with a disproportionate number of refugees. But careful analyses demonstrated that overall, the process resulted in a population distribution of refugees that mirrored state population rates fairly well, as a perfect match to existing state population densities would have required redistribution of only about one fourth of the refugees (Desbarats, 1985). However, the desire to relocate near kin and social networks, in addition to the facts that sponsors were often ill-equipped to meet the their needs, and that greater opportunity for assistance could be found in certain states such as California, created great incentive for refugees to leave sponsorships and move to communities that met all those needs (Desbarats, 1985). By 1980, population densities of Southeast Asians in certain states had more than doubled, and with almost $75 \%$ of the refugee population residing in just four states, it would have taken a relocation of more than $40 \%$ of the refugee population to match the overall U.S. population distribution (Desbarats, 1985; Kelly, 1986).

Along with secondary migration came the formation of Vietnamese ethnic enclaves, and "Little Saigons" began to emerge, particularly in the western states (Desbarats, 1985; Liu \& Geron, 2008). This worked to the advantage of Vietnamese refugees, as they were able to collectively utilize their human, social, and cultural capital to establish businesses and professional networks to assist with job placement and resource, to interface with educational institutions, and to create communities full of co-ethnic peers for their children (Bach \& CarrollSeguin, 1986; Kelly, 1986; Kim, 2002).

New waves of refugees arrived in large numbers - much larger than the initial cohortstarting in 1979 (Rumbaut, 1989, 2000). Factors that precipitated the second wave of refugee immigration involved a border war between Vietnam and China, the purging of ethnic Chinese by the Communist Vietnamese government in 1980, and the ongoing trade embargo that exacerbated deteriorating economic conditions in the country. Many Vietnamese, particularly those of Chinese ethnic heritage, fled the country en masse to escape both conflict and risk of starvation (Freeman, 1995; Rumbaut, 1989). These refugees tended to be rural farmers with little 
resource, and they loaded themselves into rickety boats to attempt a crossing into Thailand or other neighboring countries. The "boat people," as they came to be called, died in large numbers at sea when their watercraft sank or were overtaken by pirates (Pugh, 2004). Those that did survive the journey often had lost or been separated from family members, and arrived malnourished, destitute, and psychologically distressed (Montero \& Dieppa, 1982; Pugh, 2004).

Another factor pushing greater refugee immigration in the second wave involved escalation of conflict as well as an economic and agricultural crisis in Laos, which precipitated an influx of refugees from that country via camps in Thailand. After the pullout of U.S. and Allied troops from the region in 1975, the Pathet Lao forces were able to take control of Laos by December of that year (Kula, 2014). The Hmong people were persecuted for their role in assisting the U.S. forces and nearly all left Laos in the years following the war, crossing the Mekong River to Thailand either by swimming or with the assistance of bamboo "wings" strapped to their shoulders (Rumbaut, 1989; Vang \& Flores, 1999). Lowland Lao-both ethnic Lao and Khmer-also left in large numbers in order to flee the conditions they were facing (Rumbaut, 1989). Hmong refugees came with virtually no economic resource or human capital. Many had subsisted in Laos as slash-and-burn farmers, and tended to have little to no educational or occupational experience relevant to available jobs in the U.S., nor any English language knowledge (Trueba et al., 1990). Lowland Lao were more heterogeneous and included some city dwellers and educated people, though the majority also consisted of rural subsistence farmers with very little education or professional experience (Desbarats, 1985; Rumbaut, 1989).

Later arrivals within the second wave consisted of Cambodian refugees: survivors of Pol Pot's genocidal Khmer Rouge regime. These refugees had suffered greatly; Pol Pot had emptied all cities and killed religious, educational, and political leaders in an attempt to create his vision of a utopian Communist agrarian society. The entire population had been forced to engage in heavy manual labor in the fields for long hours, to live on meager rations, and to endure torturous and violent treatment by soldiers (Carlson \& Rosser-Hogan, 1991; Kim, 2002; Rumbaut, 2000). It is estimated that about one fourth of the entire Cambodian population died from torture, starvation, sickness, or exhaustion during the years of Pol Pot's rule (Kim, 2002). The Cambodian refugees who had survived the years of the Khmer Rouge regime thus generally consisted of the uneducated and unskilled laborers who had survived the genocide; additionally, they were more likely to arrive with symptoms of mental illness and to be headed by widowed mothers rather than fully intact families (Desbarats, 1985; Hinton, Rasmussen, Nou, Pollack, \& Good, 2009; Rumbaut, 1989).

While the first wave of refugees had then benefited from their relatively high educational and professional experience, the second wave had little human capital to assist them in adapting to life in the U.S. They had no English knowledge, little to no education, and no training in the types of industries for which jobs were available. To make matters worse, they arrived at a time of deep economic recession and high inflation in the U.S., and were victims of widespread xenophobia and racial discrimination that resulted both from the nation's divided stance on the war (even sympathizers experienced so-called "compassion fatigue" (Montero \& Dieppa, 1982; 
Rumbaut, 1989)) as well as fears of competition with refugees for jobs during the economic crisis (Bach \& Carroll-Seguin, 1986; Montero \& Dieppa, 1982; Portes \& Rumbaut, 2001; Rumbaut, 1989, 2000; Silverman, 1980).

The second wave was increasingly admitted as refugees through family reunification criteria rather than through the sponsorship program, allowing many immigrants a chance to settle immediately with family members (Desbarats, 1985). Secondary migration did occur for those in sponsorships with this wave as well, further solidifying the existing population trends and the formation of ethnic enclaves. As with the first wavers, these refugees were eligible for long-term welfare assistance, Medicaid, food stamps, and other forms of cash aid, as well as state-run programs that included counseling services, ESL programs, and job training (Silverman, 1980). Though second-wave refugees did take advantage of these programs in large numbers, the assistance proved to be inadequate to fully address the barriers they faced upon arrival.

A third wave of Southeast Asian immigrants lasted through the rest of the 1980s and into the 1990s; however, this "wave" was not characterized by a spike in the number of arrivals as with the first two. Instead, it was characterized by a gradual, sustained effort to bring remaining victims of the Vietnam War to the U.S. under new programs rather than through the sponsorship system, including family reunification, the Orderly Departure Program, the Amerasian Homecoming Act, and the Humanitarian Operations Program, among others (Freeman, 1995; Rumbaut, 1989, 2000). Admission from these countries under regular immigrant status rather than as refugees became increasingly common, and thus the numbers of refugee admissions slowly but steadily dwindled over the years. This third wave of refugees also tended to arrive with little education or relevant job experience (Rumbaut, 2000). By the time of their arrival, ethnic enclaves were firmly established, and they tended to be able to settle directly into these communities.

The following section will analyze the historical experiences of the Southeast Asian refugee groups against the modes of incorporation framework, characterizing the experiences of each group in positive, neutral, or negative terms in order to clarify the linkages between the history of each group and its subsequent educational and occupational trends.

\section{Modes of Incorporation and Other Barriers and Opportunities: Historical Analysis and Discussion of the Southeast Asian Case}

\section{Government Policy}

Government policy regarding immigration for all Southeast Asian groups from Indochina was receptive. Quick and decisive action was taken to prepare for and assist the immigration process of refugees as soon as the decision to pull troops from the region was made, and this assistance has continued to the present day (Paik et al., 2014; Portes \& Rumbaut, 2001). President Ford established an "Interagency Task Force for Indochina Refugees" on April 18 to coordinate efforts to assist the refugees in their resettlement, and Congress quickly passed the Indochina 
Migration and Refugee Assistance Act of 1975, which was signed by Ford on May 24, 1975, granting the Department of Health, Education, and Welfare (HEW) the power to work with the U.S. State Department to take over administration of the resettlement effort (Hing, 1997; Silverman, 1980). This policy primarily assisted the first wave in settling in the U.S. In 1980, Congress passed another, more comprehensive Refugee Act to provide better and more coordinated assistance to second-wave refugees through the newly created Office of Refugee Resettlement (ORR), that would not rely so heavily on the Volags and achieve a greater balance between public and private sector efforts (Silverman, 1980). For the third wave, three major policies were put into place to assist and encourage their immigration: The Orderly Departure Program was established to assist refugees still lingering in Thai camps or in Vietnam to be relocated with family members, the 1987 Amerasian Homecoming Act specifically assisted children of American soldiers and their Vietnamese families in immigrating to the U.S., and the Humanitarian Operations Program of 1989 allowed for the release of political prisoners in Vietnam, and their families, for settlement in the U.S. (Hidalgo \& Banks, 2008; Hing, 1997; Zhou \& Bankston, 1998). Once here, the government worked at all levels to provide ongoing cash and program assistance (e.g., through educational, occupational, and medical programs) at unprecedented levels (Montero \& Dieppa, 1982; Rumbaut, 1989, 2000; Silverman, 1980). This assistance represented a massive, concerted, and unmatched effort to aid refugee immigration and adaptation to the U.S.

\section{Societal Reception}

While government policy was receptive to the refugee immigrants from Southeast Asia, American society was decidedly prejudiced toward this group (Paik et al., 2014; Rumbaut, 1989). Gallup polls conducted in 1975 and 1980 showed that well over the majority of Americans believed that the refugees should not have been permitted to stay in the U.S. and that immigration from Southeast Asia should be halted (Montero \& Dieppa, 1982). The Vietnam War had been a point of contention and divisiveness in American politics and society, and many found the arrival of the refugees from the conflict to be an affront (Portes \& Rumbaut, 1990).

Though the literature consistently characterizes overall U.S. society as prejudiced toward Southeast Asians, Freeman (1995) notes that many first wavers experienced more ongoing support from their sponsors, which may have mitigated their experiences of prejudice and assisted in their acculturation experiences. Such was not the case for later waves (Freeman, 1995). According to Rumbaut (1989), the fact that the peak of the second wave in 1980 coincided with the worst economic crisis the U.S. had seen since the Great Depression resulted in a "sociopolitical climate of intensifying nativism, racism, xenophobia, and "compassion fatigue"" (Rumbaut, 1989, p. 99). Unemployment was already high at 9\% during this year, and many Americans feared that the new refugees would occupy the few jobs that would become available (Montero \& Dieppa, 1982). The prejudiced attitude toward Southeast Asians affected not only adults, but children as well; for example, scholars reported that teachers often either 
branded Hmong children as delinquents or as part of a model minority that didn't require their help (Lee, 2001; Trueba et al., 1990). The high achievement of some Vietnamese students was overly publicized in the press, which contributed to Southeast Asians being lumped together with other Asian groups as a "model minority" and cloaked the many difficulties that refugees and their children continued to face in regards to academic adjustment (Freeman, 1995; Zhou \& Bankston, 1998). Experiences of prejudice persisted; a later 1992 survey of second generation Southeast Asians revealed that $70 \%$ had encountered race-based discrimination (Zhou \& Xiong, 2005). This, combined with other barriers, made social, occupational, and educational advancement very difficult to attain for the newly arrived families.

\section{Co-Ethnic Communities}

Upon arrival, no co-ethnic communities existed for any Southeast Asian population, since prior immigration to the U.S. had been virtually nonexistent (Portes \& Zhou, 1993; Rumbaut, 1989). However, first-wave Vietnamese, who came with education as well as professional and business expertise, were able to quickly develop communities in which co-ethnic businesses and organizations provided existing and incoming Vietnamese with occupational and educational opportunities (Bach \& Carroll-Seguin, 1986; Kelly, 1986). This may have occurred for three main reasons. The first was that during their time in the camps awaiting processing for sponsorships, they were able to develop the social networks that would assist such an effort: "early camps helped to create the Vietnamese American communities that would emerge over the following two decades. By bringing Vietnamese together on American soil, the camps enabled them to establish or reestablish social ties and social networks" (Zhou \& Bankston, 2000, p. 17). This became particularly important for development of ethnic enclaves; the capital needed to start businesses in emerging ethnic enclaves (most notably, in Orange County in Southern California) often relied on pooled resources while social networks also often provided access to jobs (Freeman, 1995). The second reason first-wave Vietnamese immigrants were able to quickly create ethnic enclaves was that they were disproportionately placed in California, allowing the existing social networks developed in the camps to further develop into entrepreneurial partnerships and active organizational leadership (Bach \& Carroll-Seguin, 1986; Desbarats, 1985). The third involved the tremendous secondary migration that first-wavers engaged in, resulting in further concentration into emerging designated "Little Saigons" across several states (Desbarats, 1985; Kelly, 1986; Portes \& Rumbaut, 1990).

Second-wave Vietnamese, then, had the benefit of established co-ethnic communities to assist their occupational and educational opportunity through the provision of social, cultural, human, and economic capital (Kim, 2002; Zhou \& Bankston, 2000). In Orange County's "Little Saigon" in particular, ethnic businesses became dominated by ethnic Chinese Vietnamese who were able to add capital from overseas Chinese investors as well (Aguilar-San Juan, 2009). Thus, scholars have termed the Vietnamese American population as having a "strong" co-ethnic community (Paik et al., 2014; Portes \& Zhou, 1993). Research on subsequent generations has 
linked involvement in these Vietnamese co-ethnic communities, and a resultant strong Vietnamese identity, with high academic achievement, while second-generation youth who disassociate from this community have seen lower achievement (Portes \& Zhou, 1993; Zhou \& Bankston, 1994; Zhou \& Xiong, 2005).

In contrast to the Vietnamese experience, Laotian, Hmong, and Cambodian refugees did not have an "elite" first-wave that created a co-ethnic community. These immigrants tended to arrive with very little to assist their adaptation besides government and sponsor aid. These groups did also engage in secondary migration to places where co-ethnics also resided and to places were greater opportunity and/or assistance was available, and both ethnic enclaves and designated ethnic towns such as Cambodia Town in Long Beach, California and Little Mekong in St. Paul, Minnesota emerged. However, these communities still lacked the concentration of professionals and entrepreneurs who could create the needed occupational and educational opportunities to allow for broad-based social mobility (Hing, 1997; Zhou \& Bankston, 1994). Thus, these groups have been termed as having "weak" co-ethnic communities (Paik et al., 2014; Portes \& Zhou, 1993).

\section{Other Barriers and Opportunities}

Southeast Asian refugees experienced more barriers than opportunities for social advancement upon their arrival (Paik et al., 2014). While they all arrived in the more favorable post-1965 era, they were initially dispersed into all U.S. states, requiring significant secondary migration to create concentrated ethnic enclaves. All groups were disproportionately sponsored in California, and secondary migration increased the concentration of these groups into this coastal state. Settlement in metropolitan and coastal areas is normally considered a positive factor; however, only the Vietnamese and Cambodian Americans tended to establish ethnic towns along the metropolitan and coastal areas of the U.S.; by contrast, the Hmong settled in the Central Valley area of California as well as in northern Midwestern states, and Laotians remained comparatively dispersed throughout the states (Bankston, 2000; Helzer, 1994; Hmong Studies Internet Resource Center, 2011; Liu \& Geron, 2008). Moreover, all Southeast Asian groups initially tended to settle in low-income areas with high crime rates and low-achieving schools, where their children could easily assimilate into groups of low-achieving and/or delinquent peers (Portes \& Zhou, 1993; Zhou \& Bankston, 2000; Zhou \& Xiong, 2005). Thus, in terms of the factor of settlement location, the patterns of settlement remained problematic for all Southeast Asian populations, though somewhat less so for Vietnamese Americans.

In terms of class status, all groups except for the first-wave Vietnamese tended to come from very poor backgrounds and to arrive completely destitute (Rumbaut, 2000). Even the few who had enjoyed a higher class status in their home country often had to give up their possessions in order to make the journey to the U.S. (Bach \& Carroll-Seguin, 1986). This barrier proved very difficult to overcome, even with the financial assistance provided by the public and private sectors. Occupationally, very few refugees outside of the first wave had any professional 
or entrepreneurial experience; they tended to have been farmers in Asia, and upon arrival, took factory jobs at minimum wage upon arrival (Desbarats, 1985; Rumbaut, 1989; Trueba et al., 1990). Even many Vietnamese from the first-wave who came with credentials and professional experience found that those credentials were unrecognized by American organizations and institutions, and initially were placed in manual labor types of jobs (Anderson, 2005; Bach \& Carroll-Seguin, 1986; Desbarats, 1985). Education levels were also very low for most groups; the Hmong in particular rarely had any education at all, and Cambodian refugees tended to also have very little education, as the educated classes had been wiped out during Khmer Rouge rule (Kim, 2002; Takaki, 1998). Besides the first-wave Vietnamese, some second-wave Laotians who had come from the urban areas of Laos had high school and even college education, but even this group had little average education (Desbarats, 1985; Rumbaut, 2000). Finally, in terms of English language ability, the pattern remains the same; very few refugees spoke any English upon arrival, with the exception of the educated first-wave of Vietnamese refugees, and a few Hmong who had worked directly with U.S. soldiers during the war (Desbarats, 1985; Rumbaut, 1989). Learning English was particularly difficult for refugees; a large survey of $2^{\text {nd }}$-generation Southeast Asians administered in the mid-2000s revealed that less than one-third characterized their parents as able to speak English "very well" (Rumbaut, 2008).

Another key factor worthy of mention has to do with the psychological impact on refugees of the experience of fleeing their homelands. Unlike other groups who, for the most part, were able to plan their immigration and did so voluntarily, Southeast Asian refugees had little choice; and in leaving, they experienced traumatic events before and during their journeys to the U.S. For so many refugees, the experiences of the flight from their homes, their harrowing overwater journeys, and life in the refugee camps in Southeast Asia where many lingered for years, barely subsisting, had a huge impact on their psychological health (Floriani, 1980; Long, 1993; Mollica, Xingjia, McInnes, \& Massagli, 2002). Added to this was the fact that often, they had been separated from family members somewhere along the journey, which was particularly traumatic for the children involved (Harding \& Looney, 1977). It was first noted at the processing camps in the U.S. that the refugees had need of psychological services at a level that had been unexpected (Montero \& Dieppa, 1982). Cambodians had seen unparalleled atrocities, and have been especially prone to suffer from Post-Traumatic Stress Disorder as well as depression and other mental illnesses as a result, which has impacted their ability to effect upward social mobility not only for themselves, but also for their children (Carlson \& RosserHogan, 1991; Hinton et al., 2009; Kinzie, Sack, Angell, Manson, \& Rath, 1986). While the factor of psychological health is absent from the modes of Asian incorporation framework in use for this analysis, it is necessary to consider this issue as an additional barrier experienced by all Southeast Asian groups. 


\section{Linkages to Outcomes: How Modes of Incorporation Explain Attainment}

As noted earlier, all Southeast Asian groups have experienced lower educational and occupational attainment than other Asian groups and the general U.S. population, which is explained by the absence of supportive factors other than government receptivity within the modes of Asian incorporation framework. Specifically, Laotian, Hmong, and Cambodian refugee groups encountered societal prejudice without strong co-ethnic communities to buffer its effects, as well as other barriers, such as low SES, limited entrepreneurial or professional skills, and lack of knowledge of English. Together, these factors led to problematic settlement often in lowincome, urban areas, where the second and third generation had more challenges integrating into their co-ethnic communities (Portes \& Rumbaut, 2001; Portes \& Zhou, 1993). The only exception to this pattern lies with the Vietnamese American community, for whom a high percentage of academic achievers, professionals, and entrepreneurs compared to the other refugee groups can be seen. This difference can be explained by the unique first-wave group that had overall higher SES status, greater experience with English as well as with business, and for whom resettlement camp experiences allowed social networks that subsequently permitted this first wave to establish a stronger co-ethnic community to assist later waves in acculturating better to life in the U.S.

For all groups, academic attainment gains in the second generation have been noted. In addition to understanding the diverse and unique experiences of Southeast Asian groups, research into the second generation have revealed that these gains have been primarily a function of the children of refugees maintaining strong ties to their parents' ethnic community, cultural values, and motivated co-ethnic peers (Chang \& Le, 2005; Chhuon, Hudley, Brenner, \& Macias, 2010; Supple, McCoy, \& Wang, 2010; Zhou \& Bankston, 1994, 1998). These findings, together with the greater attainment of the Vietnamese group whose stronger co-ethnic community stands out, highlight the importance of co-ethnic communities in supporting positive outcomes for these refugee groups across generations.

\section{Conclusions and Implications}

Southeast Asian refugees occupy a unique place in American history. Their experiences of reception into this country provide a lens through which to understand their educational and occupational trajectories after arrival and illustrate the importance of understanding each group's diverse experiences. While Vietnamese Americans had the advantage of a first wave of refugees with enough professional, business, and entrepreneurial experience to create a strong co-ethnic community to assist later waves, this was lacking for Cambodian, Hmong, and Laotian groups. Hmong Americans had by far the least experience with modern society and had particular barriers due to the major cultural shifts required by life in America, while Cambodian refugees had experienced the greater trauma during the Pol Pot regime. Laotian Americans, as the 
smallest group, had fewer opportunities to gather together in enclaves and currently remain the most dispersed group.

Yet all groups have some elements in common: examples include a common history related to the Vietnam War; a common experience of resettlement by the U.S. government and granting of assistance afterward; a common experience of prejudiced societal reception; and a common general experience of relegation to manual labor upon entry into the U.S. Additionally, Southeast Asian students into the second generation have continued to struggle in schools; this is even true for many Vietnamese second-generation students who continue to struggle, while another segment thrives, as reflected in their bimodal attainment patterns (Ngo \& Lee, 2007; Niedzwiecki \& Duong, 2011).

The theoretical framework offers a lens through which to understand the major trends of their historical experiences and educational outcomes. In this case, the barriers of arrival with little education, English language skills, or professional and entrepreneurial experience, combined with settlement in poor neighborhoods with low-achieving peers, a lack of co-ethnic communities, and a prejudiced societal reception all contribute to Cambodian, Hmong, and Laotian American groups' abilities to secure occupational or educational upward mobility. While government receptivity and assistance did help these populations, it did so by enabling their survival rather than their advancement (Paik et al., 2014; Zhou \& Bankston, 2000). The Vietnamese case offers a glimpse into the ways in which the infusion of a cohort with greater human capital and the ability to create a stronger co-ethnic community can alter achievement patterns. Because the other factors within the modes of incorporation are similar, an examination of the Southeast Asian refugee experiences provides insight into the potential of co-ethnic community in possibly influencing outcomes.

Another major lesson that can be learned from examining these Southeast Asian immigration stories is the importance of disaggregating the Asian experience in general. Often, both educational institutions and scholars lump all Asian groups together in reporting and research, creating a false sense of homogeneity where none exists (Blair \& Qian, 1998; Fong, 2008; Lee, 1996; Ngo \& Lee, 2007). There are major between-group differences in the context of immigration, experiences of acculturation and adaptation in the U.S., and educational and occupational trends. Even attempts to disaggregate often create umbrella terms such as "East Asian," "South Asian," and "Southeast Asian;" while such research represents a step in the right direction, it is important to note that usage of these terms can mask further distinctions between ethnic groups within each category.

In the case of Southeast Asian groups studied here, the "model minority myth" commonly held about Asian American children can mask their educational needs, leaving them unmet (Lee, 2001; Ngo \& Lee, 2007). Conversely, teachers who understand the tremendous barriers faced by Southeast Asian groups can negatively stereotype these students as "delinquents" and hold lowered expectations for them (Lee, 2001; Trueba et al., 1990). A true understanding of the nature of Southeast Asian immigration experiences should result in a greater awareness of the barriers that families and individuals from these groups may face, and 
an increased commitment to help them overcome any obstacles to learning. Given the evidence presented in this article regarding the importance of integration into the co-ethnic community, such efforts would specifically encourage positive ethnic identity formation. One way to accomplish this would be through the provision of continued language supports, especially including bilingual education opportunities for subsequent generations, since language use is a key aspect of cultural adhesion (Portes \& Rumbaut, 2001), and translators for parents in areas of high concentration of Southeast Asian Americans. Such programs would serve as appropriate strategies to assist parents in their abilities to sustain their language communities while interfacing effectively with schools.

No one is certain what the future holds for these groups. Over time, statistics show an upward trend in educational attainment for all Southeast Asian Americans, as well as an increase in workers within the professional, managerial, and business sector (Niedzwiecki \& Duong, 2004, 2011), which could potentially help in the formation of stronger co-ethnic communities and social networks that encourage positive ethnic identity formation. To the extent that policy and practice can encourage the development of entrepreneurship within each ethnic group, as well as higher educational attainment, research suggests that these communities may experience broad-based improvement in outcomes. Especially for those who work with Southeast Asian children and youth in educational settings, whether in research or practice, it is vital to understand the factors that have contributed to the current achievement patterns of each Southeast Asian American group, and to work from that place of understanding to best meet the needs of individual students, in order to help each of them to achieve their full potential.

\section{Endnotes}

1. This does not include the Filipino American group, which substantially exceeds even the number of Vietnamese Americans; however, Filipinos are often separated as their own category in the literature due to their very distinct immigration history (Paik et al., 2014). Also, the number of people reporting to be of Thai origin in the 2010 U.S. Census does exceed the number reporting to be of Laotian origin by a margin of just over 5,000, but only if the numbers under the category "Alone or in any combination" are used. In general, the Indochinese groups under consideration do represent the largest Southeast Asian groups.

2. Zhou and Bankston III note the existence of a fifth camp located in Guam; however, this camp served mostly as a way-station for refugees; some processing of their cases was completed on site, but almost all were then transported to one of the four stateside camps mentioned. Rarely, refugees were resettled directly in the U.S. Southern Pacific island territories, and a few also were transported back to Vietnam upon their request. 
Kula \& Paik - A Historical Analysis of Southeast Asian Refugee Communities

\section{References}

Aguilar-San Juan, K. (2009). Little Saigons: Staying Vietnamese in America. Minneapolis, MN: University of Minnesota Press.

Anderson, W. W. (2005). Between necessity and choice: Rhode Island Lao American women. In W. W. Anderson \& R. G. Lee (Eds.), Displacements and diasporas: Asians in the Americas (pp. 194-226). New Brunswick, NJ: Rutgers University Press.

Bach, R. L., \& Carroll-Seguin, R. (1986). Labor force participation, household composition and sponsorship among Southeast Asian refugees. International Migration Review, 20(2), 381404.

Bankston, C. L., III. (2000). Laotian Americans. In Gale encyclopedia of multicultural America. Retrieved from http://www.encyclopedia.com/doc/1G2-3405800099.html

Blair, S., \& Qian, Z. (1998). Family and Asian students' educational performance: A consideration of diversity. Journal of Family Issues, 19(4), 355-374.

Carlson, E. B., \& Rosser-Hogan, R. (1991). Trauma experiences, posttraumatic stress, dissociation, and depression in Cambodian refugees. American Journal of Psychiatry, 148, $1548-1551$.

Chang, J., \& Le, T. N. (2005). The influence of parents, peer delinquency, and school attitudes on academic achievement in Chinese, Cambodian, Laotian or Mien, and Vietnamese youth. Crime \& Delinquency, 51(2), 238-264.

Chhuon, V., Hudley, C., Brenner, M. E., \& Macias, R. (2010). The multiple worlds of successful Cambodian American students. Urban Education, 45(1), 30-57.

Department of Homeland Security. (2010). Yearbook of immigration statistics: 2000. Retrieved from http://www.dhs.gov/files/statistics/publications/LPR10.shtm

Desbarats, J. (1985). Indochinese resettlement in the United States. Annals of the Association of American Geographers, 75(4), 522-538.

Floriani, C. M. (1980). Southeast Asian refugees: Life in a camp. The American Journal of Nursing, 80(11), 2028-2030.

Fong, T. (2008). The contemporary Asian American experience: Beyond the model minority (3rd ed.). Upper Saddle River, NJ: Pearson Prentice Hall.

Freeman, J. M. (1995). Changing identities: Vietnamese Americans 1975-1995. Needham Heights, MA: Allyn and Bacon.

Harding, R. K., \& Looney, J. G. (1977). Problems of Southeast Asian children in a refugee camp. American Journal of Psychiatry, 134(4), 407-411.

Helzer, J. J. (1994). Continuity and change: Hmong settlement in California's Sacramento valley. Journal of Cultural Geography, 14(2), 51-64.

Hidalgo, D. A., \& Banks. (2008). Military brides and refugees: Vietnamese American wives and shifting links to the military, 1980-2000. International Migration, 46(2), 167-185. 
Kula \& Paik - A Historical Analysis of Southeast Asian Refugee Communities

Hing, B. O. (1997). Immigration policy: Making and remaking Asian Pacific America. In D. Hamamato \& R. D. Torres (Eds.), New American destinies: A reader in contemporary Asian and Latino immigration (pp. 315-324). New York, NY: Routledge.

Hinton, D. E., Rasmussen, A., Nou, L., Pollack, M. H., \& Good, M.-J. (2009). Anger, PTSD, and the nuclear family: A study of Cambodian refugees. Social Science \& Medicine, 69(9), 1387-1394.

Hmong Studies Internet Resource Center. (2011). Southeast Asian Americans 2010 Census. Retrieved from http://www.hmongstudies.org/SoutheastAsianAmericans2010Census.html

Hoeffel, E. M., Rastogi, S., Kim, M. O., \& Shahid, A. (2012). “The Asian population: 2010.” U.S. Census Briefs. Washington DC: U.S. Census Bureau.

Joseph, C., \& Matthews, J. (Eds.). (2014). Equity, opportunity and education in postcolonial Southeast Asia. New York, NY: Routledge.

Kelly, G. P. (1986). Coping with America: Refugees from Vietnam, Cambodia, and Laos in the 1970s and 1980s. Annals of the American Academy of Political and Social Science, 487, $138-149$.

Kim, R. Y. (2002). Ethnic differences in academic achievement between Vietnamese and Cambodian children: Cultural and structural explanations. The Sociological Quarterly, 43(2), 213-235.

Kinzie, J. D., Sack, W. H., Angell, R. H., Manson, S., \& Rath, B. (1986). The psychiatric effects of massive trauma on Cambodian children: I. The Children. Journal of the American Academy of Child Psychiatry, 25(3), 370-376.

Kula, S. M. (2014). Lao American migration and resettlement: Past, present, and future. In Y. W. Chan, D. Haines, \& J. H. X. Lee (Eds.), The age of Asian migration: Continuity, diversity, and susceptibility: Volume 1 (pp. 288-301). Newcastle Upon Tyne, UK: Cambridge Scholars Publishing.

Lee, S. J. (1996). Unraveling the model minority stereotype: Listening to Asian American youth. New York, NY: Teachers College Press.

Lee, S. J. (2001). More than model minorities or delinquents: Hmong American high school students. Harvard Educational Review, 73(3), 505-528.

Liu, M., \& Geron, K. (2008). Changing neighborhood: Ethnic enclaves and the struggle for social justice. Social Justice, 35(2), 18-35.

Long, L. D. (1993). Ban Vinai, the refugee camp. New York, NY: Columbia Press.

Migration Policy Institute. (2005). U.S. in Focus: The foreign-born Hmong in the United States. Washington, DC: Author

Mollica, R. F., Xingjia, C., McInnes, K., \& Massagli, M. P. (2002). Science-based policy for psychosocial interventions in refugee camps: A Cambodian example. The Journal of Nervous and Mental Disease, 190(3), 158-166.

Montero, D., \& Dieppa, I. (1982). Resettling Vietnamese refugees: The service agency's role. Social Work, 27(1), 74-81. 
Kula \& Paik - A Historical Analysis of Southeast Asian Refugee Communities

Ngo, B., \& Lee, S. J. (2007). Complicating the image of model minority success: A review of Southeast Asian American education. Review of Educational Research, 77(4), 415-453.

Niedzwiecki, M., \& Duong, T. C. (2004). Southeast Asian American statistical profile. Center Washington DC: Southeast Asia Resource Action.

Niedzwiecki, M., \& Duong, T. C. (2011). Southeast Asian American statistical profile. Washington DC: Southeast Asia Resource Action Center

Paik, S., Kula, S. M., Saito, E., Rahman, Z., \& Witenstein, M. (2014). Historical perspectives on diverse Asian American communities: Immigration, incorporation, and education. Teachers College Record 118(6), 1-45.

Portes, A., \& Rumbaut, R. G. (1990). Immigrant America: A portrait. Berkeley, CA: University of California Press.

Portes, A., \& Rumbaut, R. G. (2001). Legacies: The story of the immigrant second generation. Berkeley, CA: University of California Press.

Portes, A., \& Zhou, M. (1993). The new second generation: Segmented assimilation and its variants. Annals of the American Academy of Political and Social Science, 530, 74-96.

Pugh, M. (2004). Drowning not waving: Boat People and humanitarianism at sea. Journal of Refugee Studies, 27(4), 50-69.

Rumbaut, R. G. (1989). The structure of refuge: Southeast Asian refugees in the United States, 1975-1985. International Review of Comparative Public Policy, 1, 97-129.

Rumbaut, R. G. (1994). Origins and destinies: Immigration to the United States since World War II. Sociological Forum, 9(4), 583-621.

Rumbaut, R. G. (2000). Vietnamese, Laotian, and Cambodian Americans. In Suarez-Orozco, M. M., Suárez-Orozco, C., \& Qin-Hilliard, D. (Eds.), Theoretical perspectives: Interdisciplinary perspectives on the new immigration, Vol. 1 (pp. 232-270). New York, NY: Routledge.

Rumbaut, R. G. (2008). The coming of the second generation: Immigration and ethnic mobility in Southern California. The ANNALS of the American Academy of Political and Social Science, 620, 196-236.

Silverman, E. B. (1980). Indochina legacy: The Refugee Act of 1980. Publius, 10(1), $27-41$.

Supple, A. J., McCoy, S. Z., \& Wang, Y. (2010). Parental influences on Hmong university students' success. Hmong Studies Journal, 11, 1-37.

Takaki, R. T. (1998). Strangers from a different shore: A history of Asian Americans (Updated ed.). Boston, MA: Little, Brown.

Trueba, H., Jacobs, L., \& Kirton, E. (1990). Cultural conflict and adaptation: The case of Hmong children in American society. Albany, NY: State University of New York Press.

United States Census Bureau. (2010). Profile of general population and housing characteristics: 2010: 2010 demographic profile data. Washington, DC: U.S. Census Bureau. Retrieved from

http://factfinder2.census.gov/faces/tableservices/jsf/pages/productview.xhtml?pid=DEC_10 _DP_DPDP1\&prodType=table 
Kula \& Paik - A Historical Analysis of Southeast Asian Refugee Communities

Vang, T., \& Flores, J. (1999). The Hmong Americans: Identity, conflict, and opportunity. Multicultural Perspectives, 1(4), 9-14.

Zhou, M., \& Bankston, C. III. (1994). Social capital and the adaptation of the second generation: The case of Vietnamese youth in New Orleans. International Migration Review, 28(4), 821-845.

Zhou, M., \& Bankston, C. L. III. (1998). Growing up American. New York, NY: Russell Sage Foundation.

Zhou, M., \& Bankston III, C. L. (2000). Straddling two social worlds: The experience of Vietnamese refugee children in the United States. Urban Diversity Series No. 111. New York, NY: Office of Educational Research and Improvement, Teachers College, Columbia University

Zhou, M., \& Xiong, Y. S. (2005). The multifaceted American experiences of the children of Asian immigrants: Lessons for segmented assimilation. Ethnic and Racial Studies, 28(6), 1119-1152. 


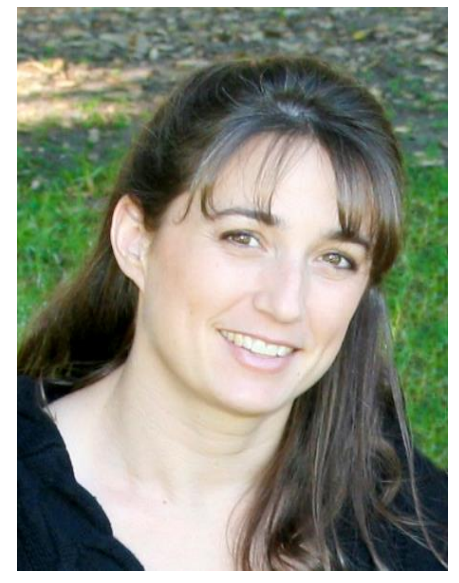

Stacy M. Kula, Ph.D. received her doctorate from the School of Educational Studies at Claremont Graduate University, and currently serves as a Senior Dissertation Chair for Grand Canyon University. Her research interests include factors of achievement for low-income immigrant students, family-community-school partnerships, multilingual education, and effective teacher education for urban contexts. She has been awarded the Tae Kim Han Award for commitment to culture and humanity in her research. Her published works have focused on Asian immigration and educational experiences (with emphasis on Indochinese groups) as well as on international and multicultural teacher education experiences.

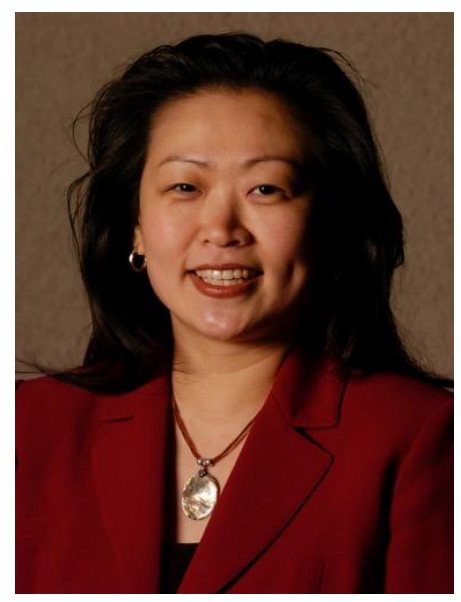

Susan J. Paik, Ph.D. is an Associate Professor in the School of Educational Studies at Claremont Graduate University. Her research interests include urban and international studies, educational productivity, talent development, minority learning and achievement, family-school-community partnerships, research methods and evaluation. She has received several awards, grants (e.g., AERA), and fellowships including the Teaching Incentive Award and Early Outreach Award for her dedication to underserved youth. Dr. Paik has a number of publications including Narrowing the Achievement Gap: Strategies for Educating Latino, Black, and Asian Students (Springer, 2007) and Advancing Educational Productivity (IAP, 2004). 


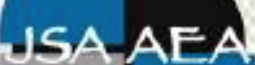

A

Volume 11 (2016)

Journal of Southeast Asian American

\title{
Education and Advancement
}

\author{
wWw.JSAAEA.org
}

\author{
Editor \\ Dr. Wayne E. Wright \\ Purdue University \\ Associate Editors \\ Dr. Chhany Sak-Humphry \\ University of Hawaii at Manoa \\ Dr. Phitsamay Sychitkokhong Uy \\ University of Massachusetts, Lowell \\ Book Review Editor \\ Dr. Vichet Chhuon \\ University of Minnesota \\ Creative Works Editor \\ Bryan Thao Worra \\ Lao Assistance Center \\ Journal Manager \\ Sung Ae Kim \\ Purdue University
}

\section{Editorial Review Board}

\author{
Dr. Steve Arounsack \\ California State University, Stanislaus \\ Dr. Sovicheth Boun \\ The State University of New York at \\ Fredonia \\ Dr. George Chigas \\ University of Massachusetts, Lowell \\ Dr. Hien Duc Do \\ San Jose State University
}

\author{
Dr. Carl L. Bankston III \\ Tulane University \\ Dr. Phala Chea \\ Lowell Public Schools
}

Dr. Loan Dao

University of Massachusetts, Boston

Dr. Changming Duan

University of Missouri, Kansas City 


\author{
Dr. Sophal Ear \\ Occidental College \\ Dr. Jeremy Hein \\ University of Wisconsin, Eau Claire \\ Dr. Nancy H. Hornberger \\ University of Pennsylvania \\ Dr. Peter Nien-Chu Kiang \\ University of Massachusetts, Boston \\ Dr. Ha Lam \\ Eastern Mennonite University \\ Dr. Jonathan H. X. Lee \\ San Francisco State University \\ Dr. Monirith Ly \\ Royal University of Phnom Penh \\ Dr. Bic Ngo \\ University of Minnesota \\ Dr. Leakhena Nou \\ California State University, Long Beach \\ Dr. Mark Pfeifer \\ SUNY Institute of Technology \\ Dr. Loan T. Phan \\ University of New Hampshire \\ Dr. Kalyani Rai \\ University of Wisconsin, Milwaukee \\ Dr. Cathy J. Schlund-Vials \\ University of Connecticut, Storrs \\ Dr. Nancy J. Smith-Hefner \\ Boston University \\ Dr. Yer J. Thao \\ Portland State University \\ Dr. Monica M. Trieu \\ Purdue University \\ Dr. Silvy Un \\ Saint Paul Public Schools \\ Dr. Terrence G. Wiley \\ Center for Applied Linguistics
}

Dr. Zha Blong Xiong

University of Minnesota

\author{
Dr. Sothy Eng \\ Lehigh University
}

University of Wisconsin, Eau Claire

Dr. Peter Tan Keo

New York University

Dr. Kevin K. Kumashiro

University of San Francisco

Dr. Ravy Lao

California State University, Los Angeles

Dr. Stacey Lee

University of Wisconsin, Madison

Dr. Sue Needham

California State University, Dominguez Hills

Dr. Max Niedzwiecki

Daylight Consulting Group

Dr. Clara Park

California State University, Northridge

Dr. Giang Pham

University of Massachusetts

Dr. Karen Quintiliani

California State University, Long Beach

Dr. Angela Reyes

Hunter College, The City University of New

York

Dr. Fay Shin

California State University, Long Beach

Dr. Christine Su

Ohio University

Dr. Alisia Tran

Arizona State University

Dr. Khatharya Um

University of California, Berkeley

Dr. Linda Trinh Vo

University of California, Irvine

Dr. Yang Sao Xiong

University of Wisconsin-Madison 


\title{
Doctoral Student Editorial Review Board
}

\author{
Virak Chan \\ University of Texas at San Antonio \\ Annie BichLoan Duong \\ San Joaquin County Office of Education \\ Hoa Nha Nguyen \\ Boston College \\ Malaphone Phommasa \\ Marshall University \\ Molly Wiebie \\ The University of Texas at Austin
}

\author{
Keo Chea-Young \\ University of Pennsylvania \\ Dung Minh Mao \\ University of Minnesota \\ Thien-Huong Ninh \\ University of Southern California \\ Krissyvan Truong \\ Claremont Graduate University \\ Soua Xiong \\ San Diego State University \& \\ Claremont Graduate University
}

\author{
Anna H. Yang \\ University of Georgia
}

